\title{
0 wild West Wind: What can a student-athlete named Alston teach global sports law?
}

\author{
Johan Lindholm ${ }^{1}$ \\ Accepted: 4 December 2021 / Published online: 13 December 2021 \\ (c) T.M.C. Asser Instituut 2021
}

On June 21, 2021, the Supreme Court of the United States (SCOTUS) handed down its decision in National Collegiate Athletic Association (NCAA) v. Alston et al. ${ }^{1}$ Alston is a noteworthy decision, not only because a court that is split on most issues was able to reach a rare unanimous decision, but also because SCOTUS declined to extend the NCAA, the sport governing body (SGB) whose regulations were being challenged, special protection from the application of competition law.

The NCAA was established by a group of American colleges and universities more than a century ago. The organization was created in response to a crisis in player safety in American football, $^{2}$ and the organization still stresses that its mission includes furthering the well-being and academic development of college athletes, along with ensuring fairness in college sports. ${ }^{3}$ The NCAA's membership has expanded significantly over time and the organization today has more than 1,000 colleges and universities that are members. Its power has also expanded over time and the NCAA now occupies a central organizational, regulatory, and enforcing role across U.S. collegiate sports.

Like many SGBs, the NCAA coordinates its members and provides harmonized regulations governing sports. The great majority of these regulations do not specifically and directly focus on or serve the economic aspects of sports, but the economic and non-economic aspects of sports and what SGBs regulate are not easily separable. This makes the organization and its actions susceptible to challenges on competition law grounds. Another obvious competition law problem is that the NCAA, again like most SGBs, enjoys a monopoly (or

\footnotetext{
1594 U. S. (2021) (henceforth Alston).

2 Alston, p. 2.

8 According to the NCAA, college sports generate close to $\$ 20$ billion per year in revenue. NCAA, Finances of Intercollegiate Athletics. Available at "https://www.ncaa.org/about/resources/research/finan ces-intercollegiate-athletics" (accessed November 14, 2021).
}

Johan Lindholm

johan.lindholm@umu.se

1 Department of Law, Umeå University, 90187 Umeå, Sweden monopsony) over a section of sports or, differently, a certain market or markets. ${ }^{4}$ For those active in sports, including both teams and individual athletes, there are in practice no realistic alternatives to accepting the governance and regulations of the dominant SGB.$^{5}$ Competition law is thus potentially applicable to many aspects of SGBs activities and acts as a controlling force. However, the competition law concerns are especially obvious when the SGB directly regulates commercial activities, is itself actively engaged in or has a financial interest in the commercial market, or some combination of the two. ${ }^{6}$

A key feature in U.S. college sports has been amateurism and it remains a policy priority from the perspective of the NCAA. Amateurism was once an ideal and foundational principle across most sports, but its hegemony over sports was significantly reduced over time, giving way for professionalization, commercialization, and commodification. From the perspective of global sports amateurism today occupies a relatively weak position. ${ }^{7}$ American college sports is however a notable exception in this regard and rules that seek to ensure amateurism constitutes a core element of the NCAA's regulatory framework. The NCAA has and enforces - both against its member colleges and universities as well as against individual athletes - a number of rules that seek to ensure that college athletes are not paid directly or directly for playing, or otherwise benefit financially from their sports.

Although the NCAA plays roles that are arguably not directly economic and many college sports and teams are not commercially successful, it is obvious that the NCAA also oversees, regulates, and participates in a multi-billion dollar industry. ${ }^{8}$ In this regard, the NCAA does not only

\footnotetext{
${ }_{3}$ NCAA, Mission and Priorities. https://www.ncaa.org/mission-andpriorities. Accessed November 30, 2021.

${ }^{4}$ Cf. Case C-519/04 P, Meca-Medina \& Majcen v. Commission, ECLI:EU:C:2006:492.

${ }^{5}$ Compare Alston, p. 9, and Mutu \& Pechstein v. Switzerland, appl. nos. 40575/10 and 67474/10, paras. 113-114.

${ }^{6}$ See National Collegiate Athletic Association v. Board of Regents of the University of Oklahoma, 468 U.S. 85 (1984), pp. 100-101, fn. 22.

7 See generally Lincoln Allison, Amateurism in Sport: An Analysis and Defence (Routledge, London 2001).
} 
exercise significant, monopoly-like power over essentially all actors involved in college sports, the NCAA and its members are themselves actively involved in that industry. The NCAA started to increasingly focus on maximizing the commercial aspects of college sports in the 1970s and 1980s, ${ }^{9}$ and the broadcasting rights to the college basketball tournament organized by the NCAA alone are worth more than $\$ 1$ billion per year. ${ }^{10}$ This development has prompted and opened up the NCAA to competition law litigation. In 1984, in NCAA v. Board of Regents, SCOTUS refused to grant the NCAA a general exception from antitrust law and ruled that its television plan constituted an anti-competitive agreement in violation of U.S. competition law. ${ }^{11}$

The respondents in Alston consisted of a group of current and former college athletes who brought their action as a class action. The respondents challenged the compatibility of the amateurism principle and, more specifically, an NCAA ban on athletes making income from their "name, image, and likeness" (NIL) with U.S. competition law. Alston can see against the background and continuation of a 2015 decision, O'Bannon v. NCAA, where a federal appellate court held that certain NCAA NIL-rules constituted unlawful restrictions of competition. ${ }^{12}$ Put simply, the problem at the core of the dispute is that so-called student-athletes playing college football and basketball serve as the basis for a multi-billion dollar industry that commercially benefit the NCAA, its member colleges and universities, coaches, and pretty much everyone involved in college sports besides, at least directly and individually, the athletes. ${ }^{13}$

The NCAA did not dispute in Alston that it enjoyed monopoly power over the market, nor that its amateurism rules had the effect of reducing athletes' compensation compared to a market characterized by free competition. ${ }^{14}$ The NCAA's defense primarily consisted of asking the Supreme Court to provide it with a type of "immunity" from the normal application of competition law. ${ }^{15}$ Its plea rested inter alia on the claim "that it seeks to "maintain amateurism in college sports as part of serving [the] societally important

\footnotetext{
${ }^{9}$ Holden et al. (2021, p. 8).

10 Alston, p. 7.

11 National Collegiate Athletic Association v. Board of Regents of the University of Oklahoma, 468 U.S. 85 (1984).

12 Ed O'Bannon v. National Collegiate Athletic Association, 802 F.3d 1049 (9th Cir. 2015).

13 See e.g., Lawrence M. Kahn, "Cartel Behavior and Amateurism in College Sports," Journal of Economic Perspectives, vol. 21(1) pp. 209-226 (2007).

14 Alston, pp. 14, 17-18. To claim otherwise would be laughable.

15 Alston, pp. 2, 22.
}

non-commercial objective' of "higher education." ${ }^{\text {"16 }}$ SCOTUS declined to grant the NCAA any such immunity which would mean to "overlook its restrictions because they happen to fall at the intersection of higher education, sports, and money..." or because "their restraints of trade serve uniquely important social objectives beyond enhancing competition." ${ }^{17}$ If the NCAA sought to secure a general exception from competition law, the Supreme Court directed the organization to the legislator who, in the Court's mind, was the proper addressee for such requests, not courts. ${ }^{18}$

On a direct and immediate level Alston concerns studentathletes' right to NIL in the rather distinct context of U.S. collegiate sports. On this level, the decision may primarily seem to be relevant in a U.S. context. As U.S. college sports has been one of the strongest remaining bastions of amateurism, a principle of that was traditionally important across most sports, Alston may be of interest to some outside the U.S., even though the eroding principle no longer holds the importance it once did. It is however also worth considering whether Alston could offer sports law some more general insight into how competition law can and should be applied to SGBs. A particularly interesting and broadly relevant question raised in Alston is whether, to what extent, and in what way SGBs can raise their pursuit of general, systemic (non-economic) aims as a defense under competition law. Perhaps Alston heralds a shift in how the "specificity of sport" is included in competition law analysis? If so, that could have potentially far-reaching consequences for sports more generally. It is more difficult to say whether what this would mean in the long term. "O Wind, If Winter comes, can Spring be far behind?"19

While being cognizant of the significant factual and legal difference, Alston shares some commonalities with the European Superleague case ${ }^{20}$ currently lodged with the Court of Justice of the European Union (CJEU). In the spring of 2021, twelve of Europe's largest and most successful (both from a sporting and economic perspective) football clubs announced that they were forming their own intra-European league: the European Superleague (ESL). This initiative faced significant opposition from, among others, FIFA, UEFA, national football leagues, politicians, and fans, and nine of the twelve clubs quickly surrendered the project. Three clubs did however press on and have launched a legal challenge against the actions of FIFA and UEFA actions before a Madrid Commercial Court. The remaining ESL clubs argue that the measures are anti-competitive and that

\footnotetext{
16 Alston, p. 22.

17 Alston, p. 22.

18 Alston, p. 24.

19 Percy Bysshe Shelley, "Ode to the West Wind."

${ }^{20}$ Case C-333/21, European Superleague Company.
} 
the SGBs seek to use their dominant position to regulate the market to prevent the creation of competing sport competitions, ${ }^{21}$ and that they therefore violate European Union (EU) competition law.

Although they come across as less sympathetic, the plaintiffs in European Superleague bares some similarities to the respondents in Alston: they are subject to SGB measures that undisputedly restrict their income compared to if there was free competition on the market and that also directly economically benefit the SGBs and their members. The two cases are also similar in that it is by merit of their monopoly power that the SGBs can impose these measures and it is also likely that the SGBs defense will center around the systemic aspects of football, along with its pro-social interests.

In this regard, European Superleague has the potential for being an Alston-moment for the CJEU. Will the CJEU go down a similar route as SCOTUS, referring UEFA and FIFA to the EU's political institutions if they need a "special" competition law approach? Or will it follow the path suggested by the EFTA Court in Kristoffersen? In the case, an SGB was allowed to justify measures that restrict individual athletes' sponsorship rights and reserve marketing revenues to the SGB itself on the ground that they ensured "a stable basis for [it's] activities." 22 The latter seems more likely than the former, but it is also possible that the CJEU uses some alternative approach.

Publisher's Note Springer Nature remains neutral with regard to jurisdictional claims in published maps and institutional affiliations.

\footnotetext{
21 The EFL would most importantly be a direct competitor to UEFA's Champions League and Europa League.

${ }^{22}$ Case E-8/17, Henrik Kristoffersen v. the Norwegian Ski Federation, para. 115.
} 